\title{
The Quigrich, or Crosier of ST Fillan
}

\author{
by the Lord Talbot De Malahide F.S.A., M.R.I.A.
}

To cite this article: by the Lord Talbot De Malahide F.S.A., M.R.I.A. (1859) The Quigrich, or Crosier of ST Fillan, Archaeological Journal, 16:1, 41-52, DOI: 10.1080/00665983.1859.10851105

To link to this article: http://dx.doi.org/10.1080/00665983.1859.10851105

$$
\text { 曲 Published online: } 10 \text { Jul } 2014 .
$$

Submit your article to this journal $\widetilde{ }$

\footnotetext{
Q View related articles $๘$
} 


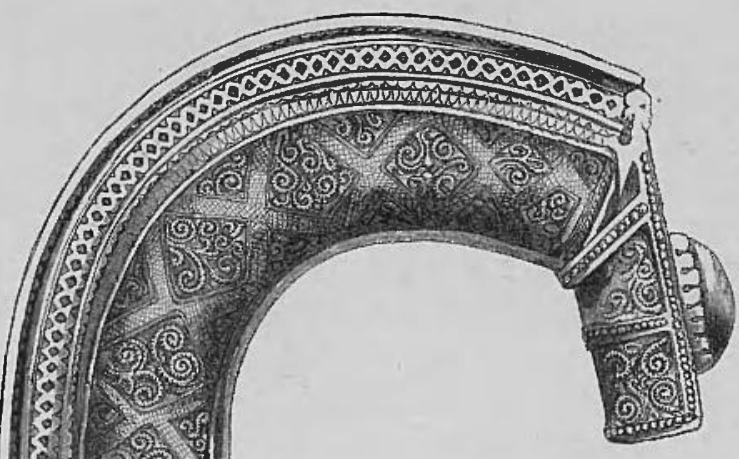

ఏ)

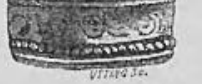

The Quifrich, or Crosiar of St. Fillan, now in Upper Canada.

From a photograph presented to the Institute by Sir Edmund W. Head, Bart., Gorernor General of Canada.

Height of the original, 9 inches. Diameter at the curve, about 61 inches. 
THE QUIGRICH, OR CROSIER OF ST FILLAN.

WITH $\triangle$ NOTICE OF ITS PRESENT EXISTENCE IN CANADA.

COMMUNICATED BT THE LORD TALBOT DE MALAHIDE, F.S.A., M.R.I.A.

PRESIDENT OF THE AROHEOLOGICAL INSTITUTE.

THE singular veneration, with which certain relics of primitive missionary bishops in Scotland and in the sister kingdom have been regarded, is well known to all who have investigated the memorials connected with our earlier Ecclesiastical Antiquities. This remarkable respect towards these objects of personal use, associated with the sacred functions of the first preachers of Christian faith, arrested the attention of the learned chaplain of Henry II., Giraldus de Barri, nearly seven centuries ago. . In the sister kingdom numerous examples occur, as might naturally be expected, of this peculiar cultus, connected with the tangible relics of the first apostles of Christianity ; whilst in Scotland, notwithstanding that systematic eradication of every relic associated with rites or dogmas of the old faith, carried out by the reformers of the sixteenth century, memorials of the primitive preachers of Christian doctrine are not wanting; scarcely less remarkable as exemplifying a tenacious adherence to popular tradition, than as productions of artistic skill and taste in times commonly regarded as barbarous.

The historian, whose name has been cited, Giraldus Cambrensis, one of the earliest writers on the Topography of the British Islands, from personal observation, makes especial mention, in his Topograpliza Hibernia, for which he collected materials, it is believed, about the year 1185, of the great reverence with which the hand-bells and pastoral staves of primitive Christian preachers were preserved in Ireland, and also in Scotland and Wales.

This statement of the bishop-elect of St. Darid's is so 
closely conformable to the popular belief still retained in regard to certain relics of this description, that it may be desirable to cite his own words.- "Hoc etiam non prætereundum puto; quod campanas bajulas, baculosque Sanctorum in superiore parte recurvos, auro et argento vel ære contectos, in magna reverentia tam Hiberniæ et Scotiæ, quam et Grwalliæ populus et clerus habere solent. Ita ut sacramenta super hrec, longe magis quam super Evangelia, et præstare vereantur, et pejerare. Ex vi enim quadam occulta, et iis quasi divinitus insita, necnon et vindicta (cujus præcipue Sancti illi appetibiles esse videntur) plerumque puniuntur contemptores ; et graviter animadvertitur in transgressores." 1

Dr. Wilson, in his Prehistoric Annals of Scotland, has described several examples of the ancient campana bajula, the clocca or clay of the primitive Scottish Christians. Some of these bells were produced in the Museum at the Meeting of our Society in Edinburgh, in 1856. The bell of St. Kentigern, patron of Glasgow, still appears in the arms of the modern city. In later times such a relic, divested of sacred character, became evidence of hereditary rights to the custodier, as in the instance of the Bell of St. Medan, resigned in 1447 by its hereditary curator to Sir John Ogilvy. A record of this transaction has been preserved among the Airlie muniments. ${ }^{2}$ The honour attached to the custody of sacred relics, as Dr. Wilson has remarked, occasioned in various cases the creation of special offices, with emoluments and lands pertaining to their holders; and the transference of these to lay impropriators, on the overthrow of the ancient ecclesiastical system, has led to the preservation of some few of the relics of primitive Scottish Saints, even to our own day. ${ }^{3}$ Among objects of this nature the Bell and the Crosier of St. Fillan, the latter known as the Quigrich, were preserved at Killin in Perthshire, and held in reverence for miraculous efficacy, almost to the close of the eighteenth century.

The bell has disappeared, having, as it has been stated, been "stolen by an English antiquarian" at the commencement of the present century. Pennant visited the ruined chapel of the Celtic Saint of Strathfillan, and he describes the peculiar healing gifts ascribed to him, but he does not

\footnotetext{
1 Giraldus Cambrensis, Topogr. Hiberniæ, tertia distinetio, cap. xxxiii, ; ap. Camdeni Anglica, \&c., p. 747.
}

2 Printed in the Spalding Miscellany, vol. v. See Appendix to this Memoir.

3 Prehistoric Annals, p. 660. 
appear to have known of the bell or the crosier. The earliest notice of the existence of the latter is to be found in the letter addressed to the Earl of Buchan by Mr. W. Thomson, student of Christchurch, Oxford, communicated to the Society of Antiquaries of Scotland in 1785. ${ }^{4}$

His account is as follows:- "At Killin, July 5, 1782, in the house of Malice Doire, a day labourer, I was shown what he called the Quigrich. It is the head of a crosier, formerly belonging to St. Fillan, who gave his name to a neighbouring Strath ..... With it is shown a copy of the King's letters of appropriation and security, which I have carefully transcribed. ${ }^{5}$ The neighbours conducted me to the envied possessor of this relic, who exhibited it according to the intent of the royal investment. A youth of nineteen, the representative of his father's name, and presumptive heir to this treasure, lay drooping in an outer apartment, under the last gasp of consumption. I am induced to advertise the Society of this circumstance, lest the relic in question should, at the death of the present owner, become a sacrifice to the neediness of his heirs, and find a ready passage to the melting-pot." Mr. Thomson sent a hasty sketch of this curious relic ; it was engraved to accompany his notice in the Archæologia Scotica, and he describes the crosier-head as of silver gilt, weighing 7 or $8 \mathrm{lbs}$. ; hollow at one end for the insertion of the staff; the recurved extremity terminating in a flat surface, on which was engraved "a crucifix, having a star on each side of the body;" and an oval crystal was set on the front of this recurved part.

A memorandum in pencil appears on this communication, to the following effect :- " The owner of the relic afterwards emigrated to America, carrying the Quigrich with him."

Dr. Wilson, in the Archeology of Scotland, p. 664, cites Mr. Thomson's interesting notice of the Quigrich, and copies the woodcut given in the Archrologia Scotica. He had been unable to illustrate his account with a more accurate representation of this very curious relic, and he quotes a letter which he had received from the Rev. Eneas M'Donell Dawson, whose own ancestors were for a time the guardians

4 Archæologia Scotica, vol. iii. p. 289.

5 This "Litera pro Maliseo Doire in Strafinane" is an official transcript of the letters of gift by James III., King of Scotland, July 11, 1487, given in by the VOL. XYI. procurator for Malice Doire, on Nov. 1, 1734 , to be registered in the Books of the Lords of Council and Session as a Probative Writ. It is printed in full hereafter. Sce Appendix to this Memoir. 
of St. Fillan's crosier, stating that it was in Canada, and in the keeping of the family to whose ancestor it was confided on the field of Bannockburn, when Robert Bruce, " displeased with the abbot for having abstracted from it the relics of St. Fillan, previously to the battle, from want of confidence, it is alleged, in the success of the Scottish cause, deprived him of the guardianship." The family, as Mr. Dawson remarked, lost possession of the crosier for a time, having disposed of it for a sum of money to an ancestor of his mother's family; and shortly after, ceasing to prosper, and attributing this change of circumstances to their indifference to a sacred object that had been solemnly entrusted to them, they persuaded the person who inherited the crosier from the purchaser to part with it in their favour. How remarkably is this in conformity with the statement of the historian of the twelfth century,'before cited :- "Ex vi quadam occulta et is quasi divinitus insita, necnon et vindicta (cujus præcipue Sancti illi appetibiles esse videntur) plerumque puniuntur contemptores."

Mr. Dawson stated at the same time, that he learned from a gentleman resident in the same parish in Canada as the emigrant custodiers of the Quigrich, that he had seen it; that overtures for its restoration to Scotland had been made by a Mr. Bruce, of London (doubtless the late Lord Elgin), and that $£ 500$ was the sum named as its ransom. $\dot{A}$ subsequent effort for its recovery, by a gentleman possessing estates in Strathfillan, proved equally unsuccessful.

During the past year the Institute has been indebted to the kind consideration of the Governor-General of Canada, Sir Edmund W. Head, Bart., for the following highly interesting communication, accompanied by three photographs of the crosier of St. Fillan, from which the accompanying representations have been reproduced.

The following is an abstract from his Excellency's letter, addressed to Lord Talbot de Malahide :-

Governatent House, Toronto, Canada, W.

dear lord taliot, April $17 t h, 1858$.

I venture to address you as President of the $\Lambda$ relisological Institute, and I trust that onr former acquaintance will serve as some excuse for my doing so.

At page 664 of Wilson's Archæology and Prehistoric Annals of Scotland 
will be found a description and a woodeut of the "Quigrich " or crosier of St. Fillan, with an account of its having been transported to Canada. It is still in the possession of the family who hold the warrant or patent of James III. there mentioned, and who have the original deed. The head of the crosier or pastoral staff is now in the room in which I am writing, having been brought down for me to see by one of the members of the family, who knows the owner. The latter is a farmer in a very small way, near Sarnia, on the St. Clare River, near its entrance from Lake Huron. Lord Elgin offered, I believe, $150 l$. for it, which they refused. It is a most interesting relic, both for the excellence and antiquity of its work, and for the fact that it was borne at Bannockburn.

By what I can learn the possessor would be reluctant to part with it, but it is certainly a pity that it should be exposed to all the contingencies of fortune on this side of the Atlantic.

The print in Wilson's book gives a very poor idea of its form or work. manship. The material is silver (which has been gilt) laid on copper. The crystal in the front is cracked across. I enclose for the Archæological Institute, if they are worth their acceptance, some photographic impressions which I have caused to be made, and which will show what it is really like.

Professor Wilson, who now belongs to the University of Toronto, saw the original for the first time in my room to-day.

The accompanying illustrations are executed from drawings which have been very kindly prepared by Mr. Westwood from the photographs. The details of workmanship are reproduced with a degree of accuracy, which his intimate knowledge of the conventional ornament and character of ancient relics of the period could alone ensure. The peculiar form of this crosier-head appears to have been adopted only in the ancient churches of Scotland and Ireland; in our own country the pastoral staff of a bishop or an abbot terminated in a volute, either simple, or purfled with crockets and foliage, and very frequently enclosing a figure of our Lord, the Holy Lamb, or some sacred symbol. There can be no doubt that the elaborate examples of metal-work, such as the Quigrich, the pastoral staff of St. Carthag, first bishop of Lismore, brought before the Institute by the kindness of the late Duke of Devonshire, ${ }^{6}$ and the pastoral staff of Maelfinnia, lately purchased by the Trustees of the British Museum from Cardinal Wiseman, were originally the costly coverings in which the simple baculi of the primitive fathers of the church were encased and enshrined. In like manner their rude hand-bells, mostly of iron plates riveted and dipped in melted brass, were held in no less veneration, and

\footnotetext{
${ }^{6}$ Archæological Journal, vol. vii.p. 83; figured, Archæologia, vol.xxxiii. pl.17,p. 360.
} 
were constantly preserved in shrines of precious goldsmith's work, of which examples are familiar to our readers $;^{7}$ and these casings were from time to time renewed or replaced by more costly coverings. The long-venerated Bachul of Moloc, successor of St. Columba, now preserved as a symbol of ancient tenure by the Duke of Argyll, has been reduced to its primitive simplicity, having been stripped of its precious covering, of which no trace remains except the broken nails fixed in the wood in attaching that decoration. This venerable staff is figured in the Catalogue of the Museum, at the Meeting of the Institute in Edinburgh, p. 32.

The Quigrich is described as mensuring $9 \frac{1}{2}$ inches in height, and about $6 \frac{1}{2}$ across the curve. The peculiar form of the extremity will be better understood

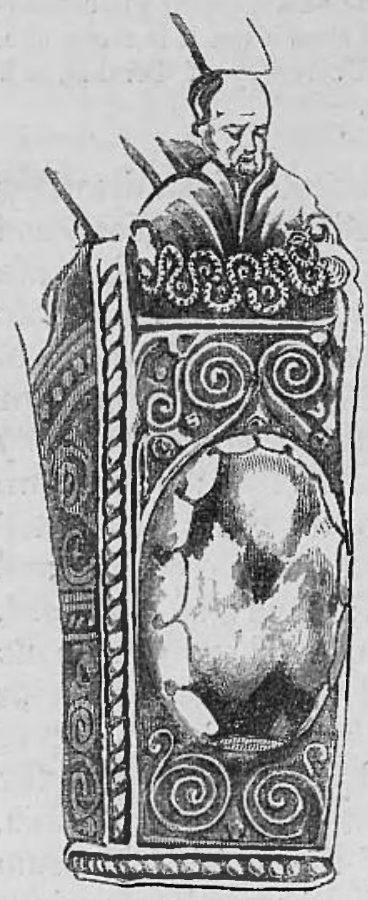
by comparison of the woodcuts, than by any description. The flat surface of the forepart is set with an uncut crystal, now cracked, and above appears a little bust, probably intended to represent the beatified St. Fillan, and placed upon filigree work of serpentine fashion, which may typify clouds, in allusion to the heavenly regions. (See woodcut, orig. size.) On the semicircular termination of this portion is engraved a crucifix, as already mentioned. The crook is ornamented with lozenge-shaped and triangular compartments of filigreework, the intervening spaces being cross-hatched; and it has a ridge or crest, enriched with several mouldings of pearled and foliated patterns. The intention of this crest appears to have been to present a flat surface upon which the hand might conveniently rest; it must be remembered that the bachul

See notices of various examples, Catalogue of the Museum of the Institute at the Edinburgh Meeting, p. 33; Archrologir Scotica, vol. iv. p. 123 ; and the
Memoir by Mr. Westwood on the portable bells of the British and Irish churchea, Archæologia Cambrensis, vol. iii., pp. 230, 301; vol. iv. pp. 13, 167. 
of the early missionary saint was doubtless originally the actual walking-staff upon which he rested in his weary pilgrimage. The crosier of a later period, with which we are more familiar, had a staff of longer proportions, and was essentially the insignia of pastoral authority. The crook, it will be observed in the accompanying woodcuts, springs from a pomel worked with compartments of semicircular and triangular shape. In the former of these there were doubtless

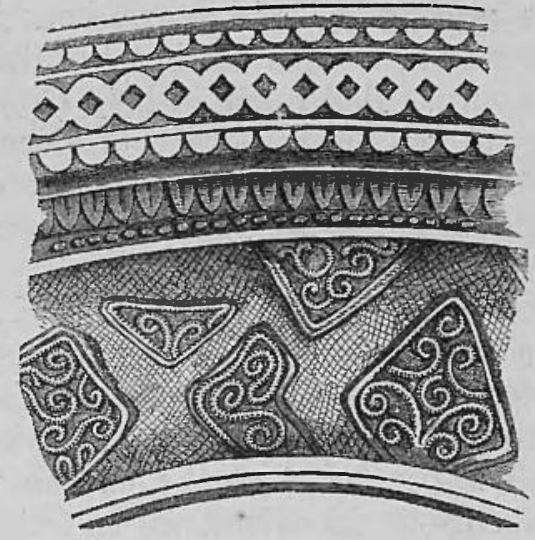

originally some enrichments affixed to the surface, enamels possibly, niello or filigree; in the intervening spaces the peculiar interlaced ornament, known as the triquetra, will be noticed. It occurs upon early metal-work, and upon sculptured monuments in Scotland and the Isle of Man, with riband-patterns and scrolls; it is found likewise upon AngloSaxon coins, namely, those of Anlaf, king of Northumbria, deposed in A.D. $944 .^{8}$

The legend of St. Fillan, as Mr. Stuart informs us, is preserved in the Breviary of Aberdeen, that venerable treasury of the traditions of the Scottish church. He is said to have been of a noble and saintly race; his mother was St. Kentigerna, daughter of a prince of Leinster. St. Fillan was baptised by St. Ybar, and at an early age entered on the monastic life under St. Mund, with whom he sojourned

8 Ruding, pl. ii. fig. 2. The simple triquetra is well shown upon the sculptured cross at Isirk Michael, Isle of Man, figured in this Journal, vol. ii,, p. 76, and in Mr. Cumming's Runic remains of the Isle of Man, plate IV. The same type of ornament, more or less complicated, is found on the greater portion of the sculptured monuments in Scotland, figured in Mr. Chalmers' and Mr. Stuart's valuable works on those remains. 
on the shores of Holy Loch, in Argyleshire, and on whose death, stated to have occurred in 962 , he was chosen his successor. Warned by a vision, St. Fillan soon after withdrew to a place in the upper parts of Glendochart, where he built a church, afterwards named Strathfillan, and there his remains were interred. The legend will be found more fully narrated by Mr. Stuart in the Miscellany of the Spalding Club, vol. iii. p. xxi. The relics of St. Fillan appear to have been venerated from an early time. Boetius has recorded the miraculous appearance of his arm-bone in the Scottish camp, which greatly comforted the heart of the Bruce on the eve of Bannockburn. Bellenden, in his "Croniklis," repeats the curious legend on the authority of Boece, and it may receive some corroboration, as $\mathrm{Mr}$. Stuart observes, from the fact that the Bruce made a gift towards the building of St. Fillan's church in 1329.

The privileges enjoyed by the custodier of the crosier of St. Fillan, called Coygerach, ${ }^{9}$ otherwise written Quigrich or Quegrith, are set forth in the Inquisition held April 22, 1428 , before the bailiff of Glendochart, where, as before stated, the Saint was interred at the church which he had founded. This curious document will be found appended to these notices, through the kindness of Mr. John Stuart, Secretary of the Antiquaries of Scotland, who has communicated a transcript from The Black Book of Taymouth, in which the original, preserved among the evidences of the Marquis of Breadalbane at Taymouth, is printed. The custodier (lator) of the relic, who was commonly called Jore, was entitled to receive annually from every inhabitant of Glendochart, a certain quantity of flour, varying according to the extent of land which each held respectively. The office of carrying or keeping the said relic had been given by the successor of St. Fillan to the ancestor of Finlay Jore, the lator at the time the inquest was taken. In consideration of these privileges, if it happened that any goods or chattels were stolen from an inhabitant of Glendochart, and he durst not make pursuit, either on account of some doubt in regard

9 The learned biographer of St. Columbr, the Rev. W. Reeves, D.D., whose edition of Adamnan's life of that saint is one of the inust important contributions to the early ecclesiastical history of the British Islands, has given an interpretation of this term, which he considers to be the Irish " coigcrioch," stranger. See notes, Life of Columba, p. 267. Iore, written also Deore, Doire, or Dewar, signifies, according to Dr. Reeves, a pilgrim. It appears, in this instance, to have been an official name, possibly from the relic being carried about, in accordanee with the duties devolving on its custodier. 
to the party, or some hostile enmity, then he should send a messenger to the said "Jore de la Coygerach," with four pence or a pair of shoes (sotularium) and provision for the first night. The said Jore was bound thenceforth to make pursuit for the recovery of the lost chattels throughout the realm of Scotland. This curious deed, as Mr. Stuart observes, is not a solitary instance of the anxious care by which it was sought to draw the fence of legal forms around the privilege of keeping the venerated relics of Scottish saints. Mr. Cosmo Innes brought under the notice of the Antiquaries of Scotland the remarkable feudal tenure which existed in the Island of Lismore, the seat of the old Bishoprick of Argyll. ${ }^{1}$ For many centuries a little estate was held by the service of keeping the bachul or staff of the patron Saint, St. Moloc, a contemporary of St. Columba. The hereditary custodiers of this relic, who enjoyed their little freehold in virtue of that trust, were long popularly known as the "barons of Bachul." The land, however, having become the property of the Duke of Argyll, the staff has been transferred to his Grace's charter room at Inverary. Mr. Cosmo Innes cites another instance of such a tenure in the case of a croft of land held, according to a charter in the fifteenth century, as an appendage to the office of keeper of the staff of St. Mund. In this instance, he remarks that "the land or the tenure (for the charter is not quite explicit) bears the name of Deowray, a name suggesting a similar office with that which gave the name of Deor or Jore (modernised Dewar) ${ }^{2}$ to the hereditary keeper of the crosier of St. Phillan in Glendochart." 3

Whilst the foregoing notices of the Quigrich were in the press, we have received, through the kindness of $\mathrm{Mr}$. Westwood, the following remarks :-

"The peculiar style of the ornamentation of this relic merits considerable attention, both on account of its great dissimilarity, when compared with most of the other remains of early Celtic art, and for the possible clue which it affords to the date of the relic itself. It will be seen both from the general figure and that of the portion represented of the full size, that the ornaments consist of a number of small triangular or quadranguiar plates,

1 Proceedings of the Society of Antiquaries of Scotland, vol. ii. p. 12.

2 The late Dr. Jamieson saw the Quigrich in possession of a person named Dewar, in Glenartney, a vale in the district of Menteith, Perthshire, near Callender. It had belonged to his ancestors from time immemorial. Jamieson's Wallace and Bruce, vol. i. p. 484.

3 Proceedings, ut supra. p. 14, where other Scottish crosiers are described by Mr. Joseph Robertson. The pastoral staff of St. Donan, in the diocese of Aberdeen, was carried about till the Reformation for the cure of fever and king's evil, p. 125 . Several notices of crosiers of the Irish Saints, similar in character, may bo found in King's Introduction to the Histors of the Primacy of Armagh. 
on which designs, chiefly spiral, are laid in filigree work, soldered to the plates. The designs are irregular, and offer no resemblance to the beautifully regular ornamentation in the oldest Irish or Hibernian-Saxon MSS. or metal work, of which latter so interesting a collection was formed at the Dublin Exhibition in 1853. There exist, however, instances of this particular treatment on several of the relics of metal work evidently of a more recent date than the twelfth or thirteenth century. The Fiocail Phadraig, or Shrine of St. Patrick's Tooth, which was exhibited by Dr. Stokes, has small plates with filigree whorls of twisted wire, fastened upon spaces between the figures representing the Crucifixion. To this I should apprehend a date not earlier than the fourteenth century must be assigned. There is a portion of similar work in the setting of the large crystal on the front of the silver cover of the Domnach Airgid. The head of a pastoral staff in the British Museum exhibits a number of small plates ornamented with twisted wire filigree work. I may also direct attention to the staff represented in Pere Martin's Melanges d'Archeologie, ${ }^{4}$ preserved in the Church of Montreuil ; I have little hesitation in regarding it as an Irish production of the thirteenth or fourteenth century. M. Martin is disposed to assign it to the eleventh century.

"In regard to these Irish pastoral staves, I may refer to two figures, Archæol. Journ., vol. vii. pp. 17 and 19, which show two modes of carrying them; St. Matthew bearing a long staff on his shoulder, whilst St. Luke carries a shorter staff as a walking stick, the crook turned outwards. I may also advert to the bronze figure of St. Canice, found near the ruined Church of Aghaboe, Queen's County, figured in the History of Killenny Cathedral, by the Rev. J. Graves. Another illustration occur's in a metal figure on the cover of an Irish Missal, formerly in the Stowe Collection, and figured by $0^{\circ}$ Conor in his Catalogue of the Stowe MSS. Dr. Petrie has given another illustration from a sculpture at Glendalough. The Ogham stone at Bressay, Shetland, exhibited at the Meeting of the Institute in Newcastle, bears representations of Bishops with short pastoral staves."

\section{DOCUMENTS RELATING TO THE RELICS OF ST. FILLAN.}

\section{Inquisitio facta de Privelegirs reliqdie Sancti Fillani. ${ }^{5}$}

Hec Inquisitio facta apud Kandrochid, xxii. die mensis Aprilis, anno Domini millesimo quadringentesimo xxvili., coram Johanne de Spens de Perth, ballivo de Glendochirde, de et super autoritate et privilegiis cujusdam Reliquie Sancti Felani, que volgariter dicitur Coygerach, per istos subscriptos, viz.: Karulum Cambell, Reginaldum Malcolmi, Donaldum McÄrthour, Cristinum Malcolmi, Johannem McNab, Patricium McNab, Johannem Alexandri McNab, Johannem Menzies, Duncanum Gregorii, Dugallum Gregorii, Duncanum Elpine, Alexandrum McAustillan, Nicolaum Gregorii, Johannem M Callum et Felanum Pauli, qui jurati magno sacramento dicunt, quod lator ipsius reliquie de Coygerach, qui Jore vulgariter dicitur, habere debet annuatim et hereditarie a quolibet inhabitante parochiam de Glendochirde, habente vel laborante mercatam terre, sive

\footnotetext{
In the article entitled Le Baton Paslorul, p. 20.

5 From the original in the Muniment Room at Taymoutl. It was printed from that document by $\mathrm{Mr}$. Cosmo Innes in the Black Book of Breadalbane. It
}

was given finst from a transcript in possession of Lord Panmure in the Miscellany of the Spalding Club, vol. iii. p. 229; and much valuable information on the subject will be found in the Preface to that volume. 
libere sue pro firma, dimidiam bollam farine; et de quolibet in dicta parochia habente dimidiam mercatam terre ut predicitur, libere vel pro firma, modium farine ; et de quolibet in ista parochia habente quadraginta denariatas terre, dimidiam modii farine. Et, si quivis alius inhabitans dictam parochiam magis quam mercatam terre haberet, nilhil magis solveret quam ordinatum fuit de una mercata terre. Et quod officium gerendi dictam reliquiam dabatur cuidam progenitori Finlai Jore latoris presentium hereditarie, per successorem Sancti Felani, cui officio idem Finlaiŭs est verus et legittimus heres. Et quod ipsa privilegia usa fuerünt et habita in tempore Regis Roberti Bruys, et in tempore omnium regum a tunc usque in hodiernum diem. Pro quibus commodis et privilegiis, prefati jurati dicunt, quod si contigerit aliqua bona vel catalla rapta esse vel furata ab aliquo dictam parochiam de Glendochirde inhabitante, et is a quo ipsa bona vel catalla rapta essent vel furata, propter dubium sue persone vel inimicitias hostium, eadem bona vel catalla prosequi non auderet, tunc unum servum suum vel hominem mitteret ad eundem Jore de le Coygerach, cum quatuor denariis vel pare sotularum, cum victu prime noctis, et tunc idem Jore abinde suis propriis expensis prosequetur dicta catalla ubicunque exinde sectum querere poterit infra regnum Scotie. Et hec universa per dictam inquisitionem fuerunt inventa, anno, die, loco et mense prenominatis. In cujus rei testimonium sigillum Johannis de Spens ballivi antedicti presentibus est appensum, anno, die, et loco supradictis.

Another Instrument, from the same source as the preceding, records that on February 9, 1468, Margaret de Striveling, lady of Glenurquha,-

In curia de Glendochyrt tenta apud Kandrocht Kilin per balivum cjusdem a Johanne M Molcalum M* Gregour petiit firmas suas de terris de Coreheynan. Qui Johannes respondebat plane in facie prefate curie, coram omnibus ibilem existentibus denegauit, et dixit quod non accepit assedationem dictarum terrarum a dicta domina Margareta, sed a Deore de Meser, et quod non tenebatur in aliquas firmas de terminis elapsis, quia solvit illas dicto Deor' a quo accepit prefatas terras. Testibus Colino Campbel de Glenürquhay milite, domino Mauricio M Nachtag, et domino Roberto M Inayr, vicariis de Inchecadyn et Kilin, Johanne de Stirling, \&c.

Litera PRO MaLISEO dOIRE, COMHORAN' IN STRAFULANE.

James, be the grace of God, King of Scottis, to all and sindri our lieges and subditis spirituale and temporale, to quhois knaulege this our lettre sal cum, greting. Forsemekle as we haue undirstand that our servitour Malice Doire and his forebearis has had ane Relik of Sanct Fulane, callit the Quegrith, in keping of us and of oure progenitouris, of maist nobill mynde, quham God assolye, sen the tyme of King Robert the Bruys and of before, and made nane obedience nor ansuere to na persoun spirituale nor temporale in ony thing concernyng the said haly Relik uthir wayis than is contenit in the auld infeftments thereof, made and grantit be oure said progenitouris; We chairg you therefor strately, and commandis that in tyme to cum, ye and ilkane of you redily ansuere, intend, and obey to the said Malise Doire, in the peciable broiking and joicing of the said Relik, and that ye, na nane of you, tak upon hand to compell nor distrenye him to mak obedience, nor ansuere to you nor till ony uthir, but allenarly to

Printed in the Archroologia Scotica, vol. iii. p. 240, and in the Miscollany of the Spalding Club, vol. iii. p. 240 , with a notice of its Registration as a Probative Writ in 1734, and, from the original, in "The Black Book of Tay mouth," p. xxxvi. 
us and our successouris, according to the said infeftment and fundatioun of the said Relik, and siclike as wes uss and wount in the tyme of oure said progenitouris of maist nobill mynde of before ; and that ye mak him nane impediment, letting, nor distroublance in the passing with the said Relik throu the contre, as he and his forebearis wes wount to do ; and that ye and ilkane of you in oure name and autorite kepe him unthrallit, bot to remane in siclike fredome and liberte of the said Relik, like as is contenit in the said infeftment, undir all the hiest pane and charge that ye and ilk ane of you may amit and inrun anent us in that pairt. Gevin undir oure priue sele, at Edinburgh, this vj. day of Julij, the yere of God $j . m$ iiii. ${ }^{c}$ lxxxvii. yeris, and of oure regnne the xxvij. yere. JAMES $R$.

\section{NOTE ON THE BELLS OF ST. FILLAN AND ST MEDAN.}

WE are indebted to the kindness of Mr. John Stuart, Secretary of the Society of Antiquaries of Scotland, for the following curious particulars :-

"The Bell of St. Fillan, as well as his Crosier, was held in great repute in old times. It is said that it usually lay on a gravestone in the churchyard of Killin, and when mad people were brought to be dipped in the saint's pool, it was necessary to perform certain ceremonies. After remaining all night in the chapel bound with ropes, the bell was set upon their head with great solemnity. It was the popular opinion that if stolen, it would extricate itself out of the thief's hands and return home ringing all the way (Old Stat. Acc., vol. 17. p. 377). According to the recent Statistical Account of the parish, the bell was stolen by an English antiquarian about forty years ago, and has not proclaimed its return as yet.

"The Bells of the Celtic Saints both in Scotland and Ireland were objects of considerable importance, and they were frequently committed to the custody of hereditary keepers in whose families they were handed down for centuries. Some years ago I arranged the charters of the Earl of Airlie, and in doing so, made transcripts of two instruments relating to one of these bells, which illustrate, in a very interesting manner, ancient usages connected with relics of this description. They were subsequently printed in the Spalding Miscellany, vol. iv. pp. 117, 118. By the first deed, dinted 27th June, 1447, Michael David, the hereditary keeper of the bell of St. Medan, appeared in presence of Sir John Ogilvy of Luntrethyne, the over-lord of the same, within his Castle of Airly, and resigned the said bell into his hands with all the pertinents thereof, after which the said Sir John Ogilvy made over the said bell to his wife Margaret Countess of Moray (here first revealed to the Peerage writers) for her liferent use ; and by a subsequent instrument, dated 18th July, 1447, and entitled "The Instrument of Sessyn of the Bell," it appears that the Countess of Moray nppeared in presence of a notary, at the house or toft belonging to the bell of St. Medan, along with her husband's brother James Ogilvy, and asked from the latter as baillie for his brother Sir John, that she should have possession or saisin, to which he agreed, and then having shut the Countess into the said toft or house, he gave possession to her by the delivery of the feudal symbols of earth and stone. It is to be presumed from the circumstances of the case that the dues exigible by the Keeper of the Bell were of some importance."

6 On this subject referenco may be made to a note by Mir, Joseph Robertson, in the Book of our Lady College, printed for the Maitland Club, Preface, p. xxy. 